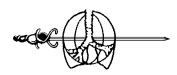

\title{
Trends in incidence and prognosis of the histological subtypes of lung cancer in North America, Australia, New Zealand and Europe
}

\author{
Maryska L.G. Janssen-Heijnen ${ }^{\mathrm{a}, *}$, Jan-Willem W. Coebergh ${ }^{\mathrm{a}, \mathrm{b}}$ \\ ${ }^{a}$ Eindhoven Cancer Registry, Comprehensive Cancer Centre South, P.O. Box 231, 5600 AE Eindhoven, The Netherlands \\ ${ }^{\mathrm{b}}$ Department of Public Health, Erasmus University Medical School, Rotterdam, The Netherlands
}

Received 1 March 2000; received in revised form 10 July 2000; accepted 31 July 2000

\begin{abstract}
Background: Since the incidence of the histological subtypes of lung cancer in industrialised countries has changed dramatically over the last two decades, we reviewed trends in the incidence and prognosis in North America, Australia, New Zealand and Europe, according to period of diagnosis and birth cohort and summarized explanations for changes in mortality. Methods: Review of the literature based on a computerised search (Medline database 1966-2000). Results: Although the incidence of lung cancer has been decreasing since the 1970s/1980s among men in North America, Australia, New Zealand and north-western Europe, the age-adjusted rate continues to increase among women in these countries, and among both men and women in southern and eastern Europe. These trends followed changes in smoking behaviour. The proportion of adenocarcinoma has been increasing over time; the most likely explanation is the shift to low-tar filter cigarettes during the 1960s and 1970s. Despite improvement in both the diagnosis and treatment, the overall prognosis for patients with non-small-cell lung cancer hardly improved over time. In contrast, the introduction and improvement of chemotherapy since the 1970s gave rise to an improvement in only short-term ( $<2$ years) — survival for patients with small-cell lung cancer. Conclusions: The epidemic of lung cancer is not over yet, especially in southern and eastern Europe. Except for short-term survival of small cell tumours, the prognosis for patients with lung cancer has not improved significantly. (C) 2001 Elsevier Science Ireland Ltd. All rights reserved.
\end{abstract}

Keywords: Lung cancer; Trends; Incidence; Prognosis; Mortality; Histology

\section{Introduction}

At the beginning of this century lung cancer was a very rare disease, but rates in North America, Australia, New Zealand and Europe have

* Corresponding author. Tel.: + 31-40-2971616, fax: + 3140-2971610. increased so dramatically that lung cancer can be

E-mail address: m.janssen@ikz.nl (M.L.G. Janssen-Heijnen). considered a major epidemic of the 20th century. 
Currently lung cancer is the first or second most frequent tumour type among men in industrialised countries and ranks second or third for women [1-5].

Trends in mortality are influenced by trends in incidence and survival. Since the incidence of the histological subtypes of lung cancer in industrialised countries has changed dramatically over the last two decades, we now review time and birth cohort trends in the incidence and prognosis of lung cancer in North America, Australia, New Zealand and Europe according to geography and histological subtype, and summarise explanations for the changes in mortality. Trends in incidence are described in the first part of this review, while the second part focuses on trends in prognosis, which so far have received little attention. We focused on industrialised countries, because the epidemic of smoking and the subsequent temporarily very high incidence of lung cancer in these countries are illustrative for other parts of the world where smoking is on the rise.

\section{Methodological considerations}

This review was based on a computerised search (Medline database 1966-2000). Included were English-written, peer-reviewed articles on trends in incidence, mortality, risk factors, prognostic factors and survival for the histological subtypes of lung cancer. We also used volumes IV to VII of 'Cancer Incidence in Five Continents', in which incidence of cancer in different geographical locations and distinct ethnic sub-populations between 1973 and 1992 are described.

\subsection{Classification}

Lung cancer is commonly classified as small-cell carcinoma and a heterogeneous group of nonsmall-cell carcinomas, which includes squamous cell carcinoma, adenocarcinoma, large-cell carcinoma, and some rare subtypes, such as adenosquamous cell carcinoma, mucoepidermoid carcinoma and adenoid cystic carcinoma. The first histological classification of lung tumours by the World Health Organization (WHO) was published in 1967 and revised in 1981 [6]. The major difference between these two classifications was that a solid carcinoma with mucus formation was classified as 'large-cell carcinoma' in 1967, and as 'adenocarcinoma' in 1981. In some papers undifferentiated carcinomas were included in the group of 'large-cell undifferentiated carcinomas', in others they were not. Large-cell undifferentiated carcinoma has frequently been called a 'wastebasket' or nonentity, because the carcinomas are so poorly differentiated that squamous or glandular differentiation is no longer evident at the light microscopic level. Thus, the incidence of this histological subtype varies with the criteria used to classify the other forms of non-small-cell lung cancer. Primary adenocarcinoma of the lung may be difficult to distinguish from pulmonary metastases of adenocarcinoma of the breast, prostate, colon, rectum or stomach. However, in most population-based or hospital-based registries the diagnosis is corrected when the primary tumour is found. Although bronchioloalveolar carcinoma is a distinct pathological entity, it is similar to adenocarcinoma as far as gender, stage, race and age distribution are concerned, but prognosis of bronchioloalveolar is probably better [7-9].

\subsection{Quality of the data}

There are differences in completeness of data between the various countries. This depends not only on the completeness of cancer registries but also on the degree of ascertainment (access to specialised care and the availability and quality of death certificates). Access to specialised care depends on the number of chest physicians and/or internists per one million inhabitants, the distance to hospitals and the extent of health insurance coverage. The completeness of cancer registries also depends on the number of sources of data, such as the pathological laboratory, hospital record offices and radiotherapy institutes. Another indicator of the completeness of the data is the mortality/incidence ratio, which should be almost equal to one in the case of this lethal disease [2]. 


\subsection{Stage migration}

When reporting on trends in stage distribution one should take 'stage migration' into account: through improved diagnostic techniques lymph node involvement or distant metastases can be found more easily, thus some tumours that were identified as localised in the past will be considered as metastasised today [10]. Stage migration will result in a better prognosis for each stage group.

\section{Trends in incidence}

\subsection{Geographical variations}

Worldwide male lung cancer incidence rates between 1988 and 1992 were highest ( $>50$ per 100000 person-years) in the USA, Canada, New Zealand (Maori) and most European countries, moderate (35-50 per 100 000) in China, Ireland, Malta, Spain, Australia and New Zealand (nonMaori), and low ( $<35$ per 100000$)$ in Utah (USA), Latin America, most Asian countries, Iceland, Norway and Sweden [2]. For women lung cancer incidence rates were exceptionally high ( $>$ 50 per 100 000) in New Zealand (Maori), high (20-50 per 100000$)$ in the USA, Canada, Denmark, Iceland and the UK, moderate (10-20 per 100 000) in Australia, New Zealand (non-Maori), Utah (USA), Austria, Germany, Ireland, The Netherlands, Norway, Poland, Sweden, Switzerland and Asia, and low ( $<10$ per 100000$)$ in Latin America, other European countries, India and Africa [2].

Incidence rates for lung cancer in industrialised countries have changed markedly over the past two decades. Fig. 1 shows the trends in age-standardised incidence rates. In North America, Australia, New Zealand and most countries of northwestern Europe the age-standardised rate for men increased markedly up to the 1970s or 1980s and then started to decline first among middle-aged men and later in the older age groups [3,11-22]. In southern and eastern Europe the peak in incidence was not reached at the beginning of the 1990s [2,20,23-25]. For women lung cancer incidence (being much lower than that for men) started to increase later and is still on the rise, except in southern Ireland and Switzerland (Geneva). In the USA, The Netherlands, Italy and Switzerland the highest rates were found for men born between 1910 and 1930 and women born after $1930[16,17,19,20,26]$.

\subsection{Variations between histological types}

The trends in lung cancer incidence were not the same for every histological type. Among men in the USA and Western Europe the age-standardised incidence rate for squamous cell carcinoma rose to 25-60 per 100000 person-years in the early 1980s and then declined to $20-40$ in the 1990s. The same trend was found for small-cell carcinoma, the peak (12-18 per 100000 personyears) also being reached at the beginning of the 1980s. The rates for adenocarcinoma rose from $5-15$ per 100000 person-years in the 1970 s to $10-35$ in the 1990s $[14,16-19,21,27-30]$; in the USA (black men) and the southeastern part of The Netherlands the peak was reached at the end of the 1980s; for white American men a plateau was reached in the early 1990s [17,18]. In other countries the peak in the incidence of adenocarcinoma had not been reached at the beginning of the 1990s.

Among European women the incidence rate for every histological type increased from 1-2 per 100000 in the 1970 s to $2-5$ in the 1990 s $[14,16-$ 19,21,27-30]. However, for American women the rise in the incidence of adenocarcinoma from 2-7 per 100000 to $13-15$ was marked [16,18,21]. In Australia and Europe squamous cell carcinoma is still the most common type of cancer among men, whereas in North America adenocarcinoma is now the leading lung cancer cell type among both men and women (Fig. 2). Adenocarcinoma is relatively more common in women (representing about one third of all lung carcinomas) than in men (15-25\% of all lung carcinomas).

There was also a birth cohort trend apparent for the different histological subtypes of lung cancer: squamous cell carcinoma declined among men born after 1910-1925, whereas adenocarcinoma only declined among men born after 
1930-1935, or even later [16,19-21]. Among women in Connecticut the incidence rates for squamous cell carcinoma and adenocarcinoma have decreased since birth cohort 1930-1939 [21], however, in Italy and Switzerland the rates for adenocarcinoma among women increased at least up to the 1950-1959 cohort [19,20]. Among Swiss women the rate for squamous cell carcinoma started to decrease with birth cohort 1940-1949 [19].

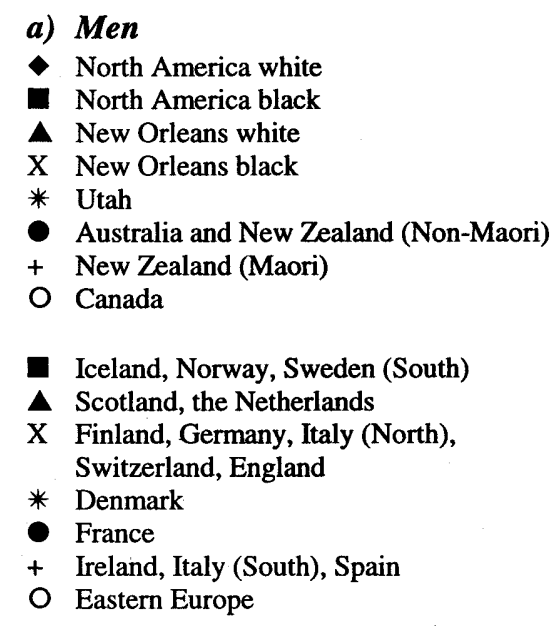

\subsection{Discussion of trends in incidence}

A lot of studies published since 1948 have indicated that smoking tobacco is the main cause of lung cancer with latency time between the start of smoking and lung cancer of 15 to 50 years [31-39]. Also the number of pack-years and the age at initiation of smoking are closely related to lung cancer risk [40,41]. A molecular link between a defined cigarette smoke carcinogen and human
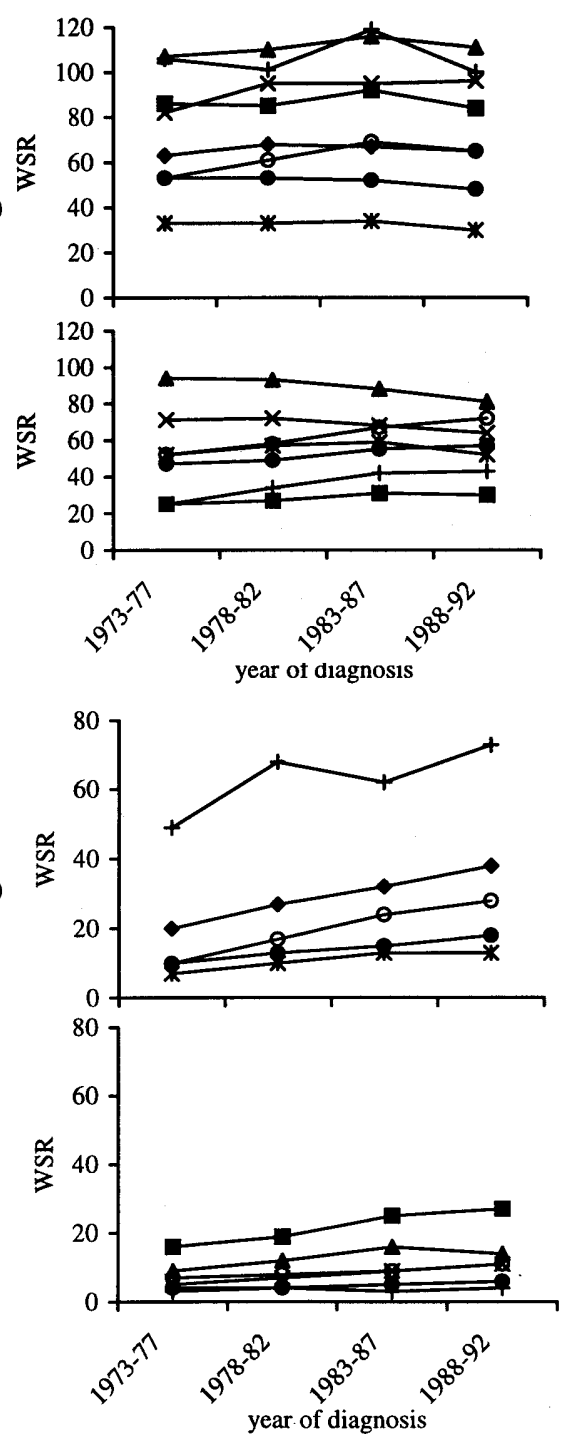

Fig. 1. Trends in age-standardized incidence rates (WSR) per 100000 person-years. Source: Cancer Incidence in Five Continents, Vols. IV, V, VI, VII. 

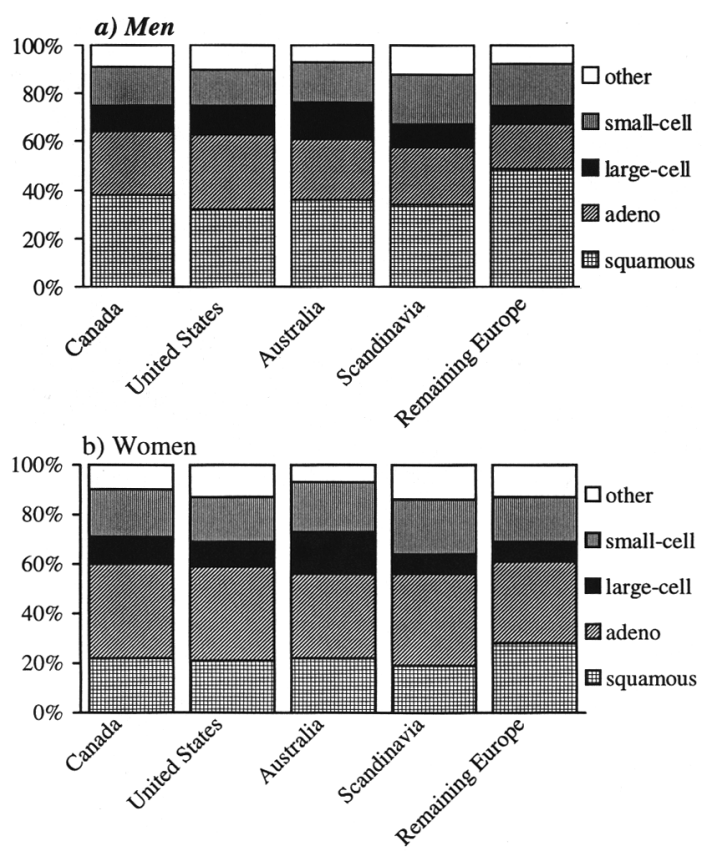

Fig. 2. Percentage distribution of microscopically verified cases by histological subtype (1988-1992). Source: Cancer Incidence in Five Continents, Vols. IV, V, VI, VII.

lung cancer mutations was not found until 1996 [42]. The relative risks of smoking are two to four times higher for squamous cell carcinoma and small-cell carcinoma (RR between 10 and 50) than for adenocarcinoma (RR between 2 and 15) [36,40,43-48]. The decline in risk after quitting smoking was also more consistent for squamous cell, small-cell and large-cell undifferentiated carcinoma than for adenocarcinoma [49]. However, the lower risk for adenocarcinoma could also be spurious, because the risk of adenocarcinoma in non-smokers ( = reference group) is also higher $[36,43,48,49]$. The association between smoking and lung cancer cell types seems to be related to tumour location: adenocarcinoma is known to occur primarily in the peripheral lung zones, whereas squamous cell carcinoma and small-cell carcinoma occur mainly in central or hilar locations [36,40,50,51]. The association between smoking and lung cancer cell type is probably related to the inhalation pattern. A case-control study conducted in the USA between 1977 and

1984 revealed that lung cancer in cigar and pipe smokers was more likely to be a central (squamous cell or small-cell carcinoma) than a peripheral lesion (adenocarcinoma); the authors speculated that cigar and pipe smoke are not inhaled as deeply as cigarette smoke [52]. Other causes of lung cancer have been identified, such as air pollution [53], occupational exposure to asbestos or radon (however, only a small proportion of the population was exposed) [54-56], vitamin A deficiency [57-61], indoor radon [62], possibly bird keeping [63-68], and previous chronic lung diseases [69-72], but the effects of smoking are so predominant that trends in other exposures seem unlikely to be largely responsible for the changes in incidence.

The trends in lung cancer incidence for both sexes followed the temporal and geographical variations in smoking behaviour after 15-25 years. The percentage of smokers among men was much higher than among women but has dropped since the 1950s/1960s, first among younger men [49,73-76]. While the prevalence of smoking has decreased since the 1950s, the percentage low-tar filter cigarette smokers among smokers has increased markedly [74,7779]. However, those who continued smoking were the heavily addicted ones [80]. In southwestern Europe the percentage of smokers did not start to decrease until the 1980s and in many eastern European countries the prevalence of smoking increased until the 1990s [76]. The very low incidence of lung cancer in Norway and Sweden can be explained by the strong anti-smoking campaigns in these countries $[48,76]$. The low incidence in Utah is probably due to the high proportion (about 70\%) of Mormons, who are discouraged from smoking. The relatively high incidence among women in New Zealand (Maori) can be explained by the high percentage of smokers.

The decrease in incidence rates for squamous cell carcinoma and small cell carcinoma was probably due to a decrease in the percentage of smokers since the 1950 s and to a change to low-tar filter cigarettes. This was not the same for men and women, nor for all age groups. The percent- 
age of female smokers was much lower than the percentage of male smokers and started to decrease only at the end of the 1970s. This has resulted in an increase in incidence up to the 1990s. Among men both a period effect (decrease in the percentage of smokers since the 1950s and a change to more low-tar filter cigarettes) and a birth cohort effect (mainly the elderly — referring to the earlier birth cohorts - continued smoking non-filter, high-tar cigarettes) occurred.

The increase in adenocarcinoma is more difficult to explain. The extent to which changes in diagnostic techniques or classification were responsible for the increase in adenocarcinoma is likely to be small $[21,30,81,82]$ : solid carcinoma with mucus production, only being classified as 'adenocarcinoma' after 1981 [6], is a very small group and is, therefore, probably not responsible for the major part of the increase. Furthermore, the inter-observer reproducibility for adenocarcinoma was good [83-85]. There are several hypotheses about changes in smoking behaviour, which could explain the increase in adenocarcinoma, which occurs primarily in the peripheral lung zones. First, the introduction of filter cigarettes since the mid-1950s may have led to an increase in the incidence of adenocarcinoma, because filters are less effective in eliminating smaller particles and filter use could also result in taking larger puffs and retaining smoke longer to compensate for the lower nicotine yield $[21,36,49,78,86]$. Since a study within the SEER database revealed that the increase in adenocarcinoma only occurred in smokers [21], the increased use of filter cigarettes seems to be a plausible explanation for the rise. Moreover, a multicentre hospital-based case-control study in the USA revealed that the risk of squamous cell carcinoma for smokers of filter cigarettes was lower than for smokers of non-filter cigarettes, but the risk of adenocarcinoma was not reduced [78]. A second, complementary hypothesis suggests that smoking low-tar filter cigarettes may increase the risk for adenocarcinoma because these cigarettes have a higher nitrate content. The increased yields of $N$-nitrosamines, especially NNK, induced adenocarcinoma of the lung in laboratory animals [87]. The higher proportion of
Americans with adenocarcinoma can also be explained by the higher proportion of smokers who smoke low-tar filter cigarettes in the USA (almost $100 \%$ in 1992) compared to European countries (about $70 \%$ ) [48,77]. The higher proportion of women with adenocarcinoma can also be explained by past smoking behaviour. Prior to the 1950s cigarettes were predominantly unfiltered, high-tar products smoked largely by men. In the 1950 s, when women were just beginning to smoke, filter cigarettes were introduced and thus represented less of a change for women than for men. This has resulted in a higher baseline proportion of women with adenocarcinoma. Most of the temporal and geographical variations in lung cancer rates are thus probably related to different patterns of past smoking behaviour.

\subsection{Conclusions concerning trends in incidence}

Although the peak of lung cancer incidence among men in North America, Australia, New Zealand and northwestern Europe was reached in the 1980 s, the rate for men in southern and eastern Europe and for women continued to increase, at least until the 1990s. The decrease in incidence first occurred in younger men, thus the proportion of elderly patients has been increasing.

The trends in incidence were closely associated with past smoking behaviour. Despite a decrease since the 1950s the percentage of smokers reached a plateau of $30-50 \%$ in the mid-1980s and teenagers have even been smoking more since 1990 [76]. Furthermore, the average number of cigarettes smoked per day has increased, because the smokers who continued smoking were the heavily addicted ones. Thus, the decrease in lung cancer incidence will probably reach a plateau in the beginning of the next century, but for those born after 1970 there will probably be an increase of lung cancer incidence after 2010.

The trend toward smoking more low-tar filter cigarettes probably caused the increase in the incidence of adenocarcinoma. This tumour type is already the major histological subtype in North America and may also become the major type in Australia, New Zealand and Europe in the near future. It is very likely that adenocarcinoma will 
give rise to a new epidemic, although it probably will not reach the same magnitude as that of squamous cell carcinoma.

\section{Trends in prognosis}

\subsection{Geographical variations}

Worldwide, the prognosis for patients with lung cancer is very poor, because metastases are often present at the time of diagnosis. Survival is associated with age and tumour stage: 1-year relative survival rates decreased from $40 \%$ for patients younger than 45 years old to $20 \%$ for patients of 75 and older [88,89], and was better for patients with localised disease $(40-65 \%)$ than for those with metastasised disease $(15-30 \%)$ [80,90-92].

In North America the 1- and 5-year survival rates in the 1980s were about 30 and $12 \%$, respectively, [93-96]. Between European countries fairly large variations in lung cancer survival rates existed between 1978 and 1989: 1-year rates varied between 21 and $42 \%$, and 5-year rates between 5 and 15\%, being highest in Finland, France, The Netherlands and Switzerland, and lowest in Denmark, England, Poland and Scotland [8890,97,98].

Between 1975 and 1990 the prognosis for lung cancer patients, regardless of histological type, improved slightly although not significantly over time $[88,89,93,95,96,98-100]$.

\subsection{Variations between histological subtypes}

Besides being dependent on age and tumour stage, survival for lung cancer patients is closely related to the histology of the tumour. Survival was best for patients with non-small-cell carcinoma and poorest for patients with small-cell carcinoma [90,92,93,97,101-106]. Despite recent advances in treatment the 5-year survival rate for patients with non-small-cell lung cancer is still less than $15 \%$ and that for small-cell carcinoma only $5 \%[92,94,97,107,108]$.

Although non-small-cell lung cancer is often considered to be one clinically uniform category, several studies indicate that survival differs ac- cording to histological subtype, being better for squamous cell carcinoma and adenocarcinoma (1year survival rates of $40-50 \%$ ) than for large-cell undifferentiated carcinoma (1-year survival rates of $25-30 \%$ ) [90,92,94,97,101,103,109]. In Yorkshire, England, UK, the population-based survival for each histological subtype of non-small-cell lung cancer remained largely unchanged between 1976 and 1983 [110]; however, the percentage of patients with an unknown histology was very high [111]. In contrast, in the southeastern part of The Netherlands the population-based relative 1-year survival rates for adenocarcinoma decreased markedly from 59\% in 1975 to $45 \%$ in 1992 , while that for squamous cell carcinoma remained about $50 \%$ and that for large-cell undifferentiated carcinoma remained about 30\% [92].

Small-cell lung cancer can be distinguished from other forms of lung cancer. Its features are: rapid progression, short doubling time, high growth fraction, and sensitivity to multiple chemotherapeutic agents and radiation therapy. Short-term survival seems to have improved since the introduction of chemotherapy in the 1970s [107,108,112]. In Mersey and Yorkshire, England, UK, the population-based 2-year survival rate improved from $2 \%$ in the 1970 s to $8 \%$ in the 1980 s and in the southeastern part of The Netherlands the population-based relative 1-year survival rate improved from $15 \%$ in the 1970 s to $35 \%$ in the 1980 s, but there was no further improvement in the 1990s and 2-year survival did not exceed $8 \%$ [106,113].

\subsection{Discussion of trends in prognosis}

Despite the improvement in survival for smallcell lung cancer, the overall prognosis for lung cancer remained poor and 5-year survival rates still do not exceed $15 \%$. Until now, the only real chance of cure is surgery for patients with limited disease [97,104,114,115]. About $30 \%$ of the patients with non-small-cell carcinoma have undergone surgical treatment since the 1980s compared to only $5 \%$ of those with small-cell carcinomas $[103,116]$. Postoperative mortality, which is higher for the elderly, is related to the type of resection, 
the risk being highest $(6 \%)$ after pneumonectomy [117].

The proportion of patients undergoing surgery decreased slightly between 1974 and 1986; for smaller lesions a trend was apparent toward more lung-sparing resections; the use of radiotherapy has increased since the 1980s [93,118]. Selection for surgery has probably improved as a result of the introduction of flexible bronchoscopy, isotope scanning and computerised tomography as well as mediastinoscopy. These diagnostic techniques have probably increased the detection of metastases (stage migration). With the exception of small-cell carcinoma there was almost no change in the proportion of patients receiving chemotherapy in the USA and the UK [93,118].

The prognosis for lung cancer varied markedly between countries, probably due to differences in (1) detection of disease, (2) inclusion of patients in studies (selected or unselected cases, patients dead around diagnosis), (3) methods of data collection and completeness (depending on access to medical care and the quality and availability of death certificates), (4) methods of calculating survival (crude, disease-specific or relative survival) and (5) access to specialised care. Furthermore, the availability of medical expertise and facilities is dependent on the number of chest physicians and internists per 100000 inhabitants. It is also influenced by geographical and socio-economic factors, including distance from specialised centres and the extent of health insurance coverage.

\subsection{Non-small-cell lung cancer}

Survival of non-small-cell carcinoma is closely associated with tumour stage and treatment. The treatment-of-first-choice for patients with stage I or II non-small-cell lung cancer is surgical resection [119]. Even for elderly lung cancer patients pulmonary resection is justified, however, a careful preoperative assessment ought to be performed and standard resections should be preferred [120,121]. Some patients with stage IIIa disease will qualify for surgical resection, others should be offered combined radiotherapy and chemotherapy. For most patients with stage IIIb disease, the preferred therapeutic modality is tho- racic radiotherapy in combination with chemotherapy [119]. For patients with stage IV lung cancer, no curative treatment or 'standard therapy' is available $[119,122]$. Although radiotherapy was applied sparingly either alone or in combination with chemotherapy for non-smallcell lung cancer, its use has doubled in the last few decades [100]. Adjuvant chemotherapy produces a significant but clinically small advantage for nonsmall-cell lung cancer patients and should still be considered experimental [119,123]. Typing of oncogenes or tumour suppressor genes may provide a more accurate diagnosis and, therefore, facilitate the planning of suitable therapeutic approaches, e.g. adjuvant chemotherapy shortly after undergoing surgery for patients with cytokeratin 18 positive stage I non-small-cell lung cancer [124-129].

Despite an excellent description of the tumour's size and the extent of anatomic spread, the tumour node metastasis (TNM) system does not include important prognostic factors that are manifest in the clinical condition of the patient [130-133]. Since the proportion of elderly patients in most Western countries is growing, co-morbidity or the coexistence of various chronic illnesses in addition to the index disease is of growing importance for the clinical management (especially surgical management) of lung cancer patients. Co-morbidity increases the risk of peroperative and postoperative complications [134-137], especially those of the cardiorespiratory system $[117,120,121,138,139]$. Co-morbidity is also an independent prognostic factor [140145]. Indeed co-morbidity in elderly patients was found to be associated with less surgery and poor survival $[100,146]$.

In the southeastern part of The Netherlands a marked decrease in survival for patients with adenocarcinoma was found, despite increased application of better diagnostic techniques by more chest physicians [92]. The decrease in survival might partly be explained by the lift of screening for tuberculosis since the early 1980s and is possibly partly due to the higher concentration of carcinogens in the peripheral lung zones - due to the increased use of filter cigarettes — which may have caused a more rapidly metastasising 
tumour. This needs to be confirmed in other countries.

\subsection{Small-cell lung cancer}

Prior to 1970 irradiation and sometimes surgery were the major modes of treatment of small-cell lung cancer. The overall 5-year survival rate with surgery was $<1-3 \%$, even for patients with clinically resectable disease. Neither preoperative nor postoperative radiotherapy improved the poor results of surgery [147]. Currently, small-cell lung cancer patients with limited disease generally receive combination chemotherapy and radiotherapy, and approximately 50\% experience complete clinical remission. Patients with extensive disease also exhibit an initial response to chemotherapy, but only $20-40 \%$ go into complete remission. Although the introduction of intensive combination chemotherapy in the 1970s has resulted in an increase in survival $[110,118]$, death from recurrent disease occurs within 2 years of diagnosis in $80-98 \%$ of the cases $[113,148-151]$. Furthermore, results of chemotherapy have reached a plateau and further improvement seems impossible with the currently available tools [106-108,152]. The response rates and survival rates after combination chemotherapy with irradiation were moderately higher than after combination chemotherapy alone [112,153-156].

For elderly patients, whose proportion has been increasing, the survival rate was lower [113,157159]. This could also be related to the presence of co-morbidity, which may complicate treatment and deteriorate the prognosis [135-137,160-162].

\subsection{Conclusions concerning trends in prognosis}

Despite earlier detection through the increased use of flexible bronchoscopy and fine needle aspiration cytology, lymphatic and hematogenous metastases are often present at the time that lung cancer is diagnosed, and prognosis is still very poor. Survival of lung cancer differs markedly, according to histological subtype. The prognosis for non-small-cell lung cancer has remained approximately constant, while the prognosis for adenocarcinoma - one of the subtypes of non-small-cell lung tumours - may even be decreasing over time. In contrast, progress has been made in the short-term survival of small-cell lung cancer - due to the introduction of chemotherapy since the 1970 s — but it has stabilised since the mid-1980s and 2-year survival remains very poor. The growing proportion of elderly patients who often present with serious co-morbidity at diagnosis complicates treatment and indicates the need for adapted guidelines for these patients, who usually are not entered in clinical trials.

\section{Summary and conclusions}

Since the beginning of this century the incidence of lung cancer has been increasing dramatically in most Western countries; it is now the most frequent or second most frequent tumour in men and the second or third in women. The peak of the epidemic among men was reached in the 1970s or 1980s in North America, Australia, New Zealand and north-western Europe, first in the younger age groups. The peak among men in southern and Eastern Europe and for women has not yet been reached. The trends were not the same for every histological subtype of lung cancer. Among men the incidence of squamous cell carcinoma and small-cell carcinoma started to decrease earlier than that of adenocarcinoma.

These trends followed changes in smoking behaviour. Among men the proportion of smokers has increased markedly since the beginning of this century but has decreased since the 1950s or 1960s, except in southern and eastern Europe. Younger men were more inclined to quit smoking or to switch to low-tar filter cigarettes than the elderly. Women only started smoking in the 1950 s and the percentage of female smokers did not decrease before the 1970s.

The incidence of and proportion of patients with adenocarcinoma have been increasing. Many studies have made it plausible that this increase is related to a shift from high-tar non-filter cigarettes toward low-tar filter cigarettes during the 1960s and 1970s, especially since the increase in adenocarcinoma was found to occur only in smokers. 
Despite improvement in both the diagnosis as a result of flexible bronchoscopy — and treatment, the overall prognosis for patients with nonsmall-cell lung cancer did not improve significantly over time. Recognition of specific patterns of mutational activation of oncogenes or disruption of tumour suppressor gene function, such as K-ras or cytokeratin 18, may facilitate tailor-made treatment and improve the prognosis for certain subgroups. In contrast, the introduction and improvement of chemotherapy since the 1970s gave rise to an improvement in - only short-term $(<2$ years $)$ — survival for patients with small-cell lung cancer. New (combinations of) chemotherapeutic agents intend to improve long-term survival for patients with small-cell lung cancer. Studies on therapy should also focus on improvement of the treatment of adenocarcinoma, because more lung cancer patients will present with this histological subtype.

In this review we have shown that the trends in the incidence of lung cancer in industrialised countries were closely associated with past smoking behaviour by birth cohort. Furthermore, except for the improvement in short-term survival of small-cell lung cancer, the prognosis has not changed significantly over the last two decades. Since mortality is influenced by both incidence and survival the following trends in mortality can be expected in the near future.

First, the decrease in mortality among men in North America, Australia, New Zealand and northwestern Europe will reach a plateau at the beginning of the next century because of the steady percentage of smokers since the 1980s and a more or less steady survival. However, the incidence of lung cancer among those born since 1970 will probably increase after 2010, because teenagers have been smoking more since 1990 . Among women in these regions mortality will start decreasing soon and will also stabilise at the beginning of the next century; the same trend is expected for men and women in southern Europe. In eastern Europe the percentage of smokers increased until the 1990s, thus a decrease in mortality is not expected before the year 2010. In other parts of the world, where smoking is still increasing, mortality due to lung cancer will increase dramatically in the next decades. Smoking can only be countered by a combined strategy of decreasing the availability of cigarettes, e.g. by increasing the price, and developing better strategies for handling nicotine addiction by offering less harmful nicotine delivery systems.

Second, the mortality of adenocarcinoma will probably increase worldwide, due to the increased use of low-tar filter cigarettes. In contrast, mortality due to squamous cell carcinoma and small-cell carcinoma will probably decrease because of a decrease in incidence and steady or slightly increasing survival rates.

In short, the epidemic of lung cancer in industrialized countries is not over yet, especially in southern and eastern Europe. Except for shortterm survival of small cell tumours, the prognosis for patients with lung cancer has not improved significantly.

\section{References}

[1] Wingo PA, Ries LAG, Giovino GA, et al. Annual report to the nation on the status of cancer, 1973-1996, with a special section on lung cancer and tobacco smoking. J Natl Cancer Inst 1999;91:675-90.

[2] Parkin DM, Whelan SL, Ferlay J et al., editors. Cancer incidence in five continents, vol VII, No. 143. Lyon: IARC Scientific Publications, 1997:992-993.

[3] Devesa SS, Silverman DT, Young JL. Cancer incidence and mortality trends among whites in the United States, 1947-84. J Natl Cancer Inst 1987;79:701-70.

[4] McCredie M, Coates M, Churches T, et al. Cancer incidence in New South Wales, Australia. Eur J Cancer 1991;27:928-31.

[5] La Vecchia C, Luccini F, Negri E, et al. Trends of cancer mortality in Europe, 1955-1989: II, respiratory tract, bone, connective and soft tissue sarcomas, and skin. Eur J Cancer 1992;28:514-99.

[6] The World Health Organization. The World Health Organization histological typing of lung tumours. Am J Clin Pathol 1982;77:123-36.

[7] Daly RC, Trastek VF, Pairolero PC, et al. Bronchoalveolar carcinoma: factors affecting survival. Ann Thorac Surg 1991;51:368-77.

[8] Barsky SH, Cameron R, Osann KE, Tomita D, Holmes EC. Rising incidence of bronchioloalveolar lung carcinoma and its unique clinicopathologic features. Cancer 1994;73:1163-70.

[9] Falk RT, Pickle LW, Fontham ET, et al. Epidemiology of bronchioloalveolar carcinoma. Cancer Epidemiol Biomarkers Prev 1992;1:339-44. 
[10] Feinstein AR, Sosin DM, Walls CE. The Will Rogers' phenomenon: stage migration and new diagnostic techniques as a source of misleading statistics for survival in cancer. New Engl J Med 1985;312:1604-6.

[11] Horm JW, Kessler LG. Falling rates of lung cancer in men in the United States. Lancet 1986;22:425-6.

[12] McCredie M, Coates MS, Ford JM. The changing incidence of cancer in adults in New South Wales. Int $\mathbf{J}$ Cancer 1988;42:667-71.

[13] Dinse GE, Hoel DG. Exploring time trends in cancer incidence. Cancer Causes Control 1992;3:409-17.

[14] Skuladottir H, Olsen JH, Hirsch FR. Incidence of lung cancer in Denmark: historical and actual status. Lung Cancer 2000;27:107-18.

[15] Vecchia L, Lucchini F, Negri E, Boyle P, Levi F. Trends in cancer mortality, 1955-1989: Asia, Africa and Oceania. Eur J Cancer ;29A 1993;29A:2168-211.

[16] Zheng T, Holford T, Boyle P, et al. Time trend and the age-period-cohort effect on the incidence of histologic types of lung cancer in Connecticut, 1960-1989. Cancer 1994;74:1556-67.

[17] Janssen-Heijnen MLG, Nab HW, van Reek J, van der Heijden LH, Schipper RM, Coebergh JWW. Striking changes in smoking behaviour and lung cancer incidence by histological type in the south-east Netherlands, 19601991. Eur J Cancer 1995;31A:949-52.

[18] Travis WD, Lubin J, Ries L, Devesa SS. United States lung carcinoma incidence trends: declining for most histologic types among males, increasing among females. Cancer 1996;77:2464-70.

[19] Levi F, Franceschi S, La Vecchia C, Randimbison L, Van-Cong T. Lung carcinoma trends by histologic type in Vaud and Neuchâtel, Switzerland, 1974-1994. Cancer 1997;79:906-14.

[20] Russo A, Crosignani P, Franceschi S, Berrino F. Changes in lung cancer histological types in Varese Cancer Registry, Italy 1976-1992. Eur J Cancer 1997;33:1643-7.

[21] Thun MJ, Lally CA, Flannery JT, Calle EE, Flanders WD, Heath CW. Cigarette smoking and changes in the histopathology of lung cancer. J Natl Cancer Inst 1997;89:1580-6.

[22] McLaughlin JR, Kreiger N, Marrett LD, Holowati ED. Cancer incidence registration and trends in Ontario. Eur J Cancer 1991;27:1520-4.

[23] Waterhouse J, Muir CS, Powell J, Shanmugaratnam K, editors. Cancer Incidence in Five Continents, vol. IV, No. 42. Lyon: IARC Scientific Publications, 1982.

[24] Muir CS, Waterhouse J, Mack T, Powell J, Whelan S. Cancer incidence in five continents, vol. V, No. 88. Lyon: IARC Scientific Publications, 1987.

[25] Parkin DM, Muir CS, Whelan SL, Gao YT, Ferlay J, Powell J. Cancer incidence in five continents, vol VI, No. 120. Lyon: IARC Scientific Publications, 1992.

[26] Devesa SS, Blot WJ, Fraumeni JF. Declining lung cancer rates among young men and women in the United States: a cohort analysis. J Natl Cancer Inst 1989;81:1568-71.
[27] Vincent RG, Pickren JW, Lane WW, et al. The changing histopathology of lung cancer: a review of 1682 cases. Cancer 1977;39:1647-55.

[28] Dodds L, Davis S, Polissar L. A population-based study of lung cancer incidence trends by histologic type, 197481. J Natl Cancer Inst 1986;76:21-9.

[29] Wu AH, Henderson BE, Thomas DC, Mack TM. Secular trends in histologic types of lung cancer. J Natl Cancer Inst 1986;77:53-6.

[30] El-Torky M, El-Zeky F, Hall JC. Significant changes in the distribution of histologic types of lung cancer: a review of 4928 cases. Cancer 1990;65:2361-7.

[31] Wassink WF. The aetiology of lung cancer. Ned Tijdschr Geneeskd 1948;92:3732-47 (in Dutch).

[32] Wynder EL, Graham EA. Tobacco smoking as a possible etiologic factor in bronchiogenic carcinoma. J Am Med Assoc 1950;143:329-36.

[33] Doll R, Hill AB. Smoking and carcinoma of the lung: preliminary report. Br Med J 1950;30:739-48.

[34] Doll R, Peto R. Mortality in relation to smoking: 20 years' observation on male British doctors. Br Med J 1976;2:1525-36.

[35] Wynder EL. Tobacco as a cause of lung cancer: some reflections. Am J Epidemiol 1997;146:687-94.

[36] Lubin JH, Blot WJ. Assessment of lung cancer risk factors by histologic category. $\mathbf{J}$ Natl Cancer Inst 1984;73:383-9.

[37] Lubin JH, Blot WJ, Berrino F, et al. Modifying risk of developing lung cancer by changing habits of cigarette smoking. Br Med J 1984;288:1953-6.

[38] Haldorsen T, Grimsrud TK. Cohort analysis of cigarette smoking and lung cancer incidence among Norwegian women. Int J Epidemiol 1999;28:1032-6.

[39] Doll R, Peto R, Wheatly K, Gray R, Sutherland I. Mortality in relation to smoking: 40 years' observations on male British doctors. Br Med J 1994;309:901-11.

[40] Denissenko MF, Pao A, Tang M, Pfeiffer GP. Preferential formation of Benzo[a]pyrene adducts at lung cancer mutational hotspots in P53. Science 1996;274:430-2.

[41] McDuffie HH, Klaassen DJ, Dosman JA. Determinants of cell type in patients with cancer of the lungs. Chest 1990;98:1187-93.

[42] Jedrychowski W, Becher H, Wahrendorf J, Basa-Cierpialek Z, Gomola K. Effect of tobacco smoking on various histological types of lung cancer. J Cancer Res Clin Oncol 1992;118:276-82.

[43] Pezzotto SM, Mahuad R, Bay ML, Morini JC, Poletto L. Variation in smoking-related lung cancer risk factors by cell type among men in Argentina: a case-control study. Cancer Causes Control 1993;4:231-7.

[44] Ellard GA, de Waard F, Kemmeren JM. Uninary nicotine metabolite excretion and lung cancer risk in a female cohort. Br J Cancer 1995;72:788-91.

[45] Siemiatycki J, Krewski D, Franco E, Kaiserman M. Associations between cigarette smoking and each of 21 types of cancer: a multi-site case-control study. Int $\mathbf{J}$ Epidemiol 1995;24:504-14. 
[46] De Waard F, Kemmeren JM, van Ginkel LA, Stolker AAM. Urinary cotinine and lung cancer risk in a female cohort. Br J Cancer 1995;72:784-7.

[47] Engeland A, Haldorsen T, Andersen A, Tretli S. The impact of smoking habits on lung cancer risk: 28 years' observation of 26,000 Norwegian men and women. Cancer Causes Control 1996;7:336-76.

[48] Morabia A, Wynder EL. Cigarette smoking and lung cancer cell types. Cancer 1991;68:2074-8.

[49] Higgins IT, Wynder EL. Reduction in risk of lung cancer among ex-smokers with particular reference to histologic type. Cancer 1988;62:2397-401.

[50] Wynder EL, Hoffmann D. Smoking and lung cancer: scientific challenges and opportunities. Cancer Res 1994;54:5284-95.

[51] Higgins ITT, Mahan CM, Wynder EL. Lung cancer among cigar and pipe smokers. Prev Med 1988;17:11628.

[52] Stellman SD, Garfinkel L. Lung cancer risk is proportional to cigarette tar yield: evidence from a prospective study. Prev Med 1989;18:518-25.

[53] Vena JE. Air pollution as a risk factor in lung cancer. Am J Epidemiol 1982;116:42-56.

[54] Saracci R. The interactions of tobacco smoking and other agents in cancer etiology. Epidemiol Rev 1987;9:175-93.

[55] Sankila RJ, Karjalainen ES, Oksanen HM, Hakulinen TR, Teppo LHI. Relationship between occupation and lung cancer as analyzed by age and histologic type. Cancer 1990;65:1651-6.

[56] Wilkinson P, Hansell DM, Janssens J, et al. Is lung cancer associated with asbestos exposure when there are no small opacities on the chest radiograph? Lancet 1995;345:1074-8.

[57] Margetts BM, Jackson AA. Interactions between people's diet and their smoking habits: the dietary and nutritional survey of British adults. $\mathrm{Br}$ Med J 1993;307:1381-4.

[58] Dorant E, van den Brandt PA, Goldbohm RA. A prospective cohort study on Allium vegetable consumption, garlic supplement use and the risk of lung carcinoma in The Netherlands. Cancer Res 1994;54:6148-53.

[59] Scali J, Astre C, Segala C, Gerber M. Relationship of serum cholesterol, dietary and plasma $\beta$-carotene with lung cancer in male smokers. Eur J Cancer Prev 1995;4:169-74.

[60] Serdula MK, Byers T, Mokdad AH, Simoes E, Mendlein JM, Coates RJ. The association between fruit and vegetable intake and chronic disease risk factors. Epidemiology 1996;7:161-5.

[61] Ziegler RG, Colavito EA, Hartge P, et al. Importance of $\alpha$-Carotene, $\beta$-Carotene, and other phytochemicals in the etiology of lung cancer. J Natl Cancer Inst 1996;88:6125.

[62] Lubin JH, Boice JD. Lung cancer risk from residential radon: meta-analysis of eight epidemiologic studies. J Natl Cancer Inst 1997;89:49-57.
[63] Holst PA, Kromhout D, Brand R. For debate: pet birds as an independent risk factor for lung cancer. Br Med J 1988;27:1319-21.

[64] Gardiner AJS, Forey BA, Lee PN. Avian exposure and bronchogenic carcinoma. Br Med J 1992;305:989-92.

[65] Kohlmeier L, Arminger G, Bartolomeycik S, Bellach B, Rehm J, Thamm M. Pet birds as an independent risk factor for lung cancer: case-control study. $\mathrm{Br}$ Med J 1992;305:986-9.

[66] Alavanja MCR, Brownson RC, Berger E, Lubin J, Modigh C. Avian exposure and risk of lung cancer in women in Missouri: population based case control study. Br Med J 1996;313:1233-5.

[67] Modigh C, Axelsson G, Alavanja M, Andersson L, Rylander R. Pet birds and risk of lung cancer in Sweden: a case-control study. Br Med J 1996;313:1236-8.

[68] Morabia A, Stellman S, Lumey LH, Wynder EL. Parakeets, canaries, finches, parrots and lung cancer: no association. Br J Cancer 1998;77:501-4.

[69] Samet JM, Humble CG, Pathak DR. Personal and family history of respiratory disease and lung cancer risk. Am Rev Respir Dis 1986;134:466-70.

[70] Skillrud DM, Offord KP, Miller RD. Higher risk of lung cancer in chronic obstructive pulmonary disease: a prospective, matched, controlled study. Ann Intern Med 1986;105:503-7.

[71] Tockman MS, Anthonisen NR, Wright EC, Donithan MG. Airways obstruction and the risk for lung cancer. Ann Intern Med 1987;106:512-8.

[72] Alavanja MCR, Brownson RC, Boice JD, Jr, Hock E. Preexisting lung disease and lung cancer among nonsmoking women. Am J Epidemiol 1992;136:623-32.

[73] Devesa SS, Grauman DJ, Blot WJ, Fraumeni JF, Jr. Cancer surveillance series: changing geographic patterns of lung cancer mortality in the United States, 1950 through 1994. J Natl Cancer Inst 1999;91:1040-50.

[74] Brown CC, Kessler LG. Projections of lung cancer mortality in the United States: 1985-2025. J Natl Cancer Inst 1988;80:43-51.

[75] Fiore MC, Novotny TE, Pierce JP, Hatziandreu EJ, Patel KM, Davis RM. Trends in cigarette smoking in the United States: the changing influence of gender and race. J Am Med Assoc 1989;261:49-55.

[76] Franceschi S, Naett C. Trends in smoking in Europe. Eur J Cancer Prev 1995;4:271-84.

[77] Wynder EL, Muscat JE. The changing epidemiology of smoking and lung cancer histology. Environ Health Perspect 1995;103(Suppl. 8):143-8.

[78] Stellman SD, Muscat JE, Thompson S, Hoffmann D, Wynder EL. Risk of squamous cell carcinoma and adenocarcinoma of the lung in relation to lifetime filter cigarette smoking. Cancer 1997;80:382-8.

[79] Giovino GA, Henningfield JE, Tomar SL, Escobedo LG, Slade J. Epidemiology of tobacco use and dependence. Epidemiol Rev 1995;17:48-65.

[80] Wersäll JP, Eklund G. The decline of smoking among Swedish men. Int J Epidemiol 1998;27:20-6. 
[81] Beard CM, Jedd MB, Woolner LB, Richardson RL, Bergstralh EJ, Melton LJ. Fifty-year trend in incidence rates of bronchogenic carcinoma by cell type in Olmsted County, Minnesota. J Natl Cancer Inst 1988;80:1404-7.

[82] Caldwell CJ, Berry CL. Is the incidence of primary adenocarcinoma of the lung increasing? Virchows Arch 1996;429:359-563.

[83] Greenberg ER, Korson R, Baker J, Barrett J, Baron JA, Yates J. Incidence of lung cancer by cell type: a population-based study in New Hampshire and Vermont. J Natl Cancer Inst 1984;72:599-603.

[84] Campobasso O, Andrion A, Ribotta M, Ronco G. The value of the 1981 WHO histological classification in inter-observer reproducibility and changing pattern of lung cancer. Int J Cancer 1993;53:205-8.

[85] Brownson RC, Loy TS, Ingram E, et al. Lung cancer in nonsmoking women: histology and survival patterns. Cancer 1995;75:29-33.

[86] Wynder EL, Covey LS. Epidemiologic patterns in lung cancer by histologic type. Eur J Cancer Clin Oncol 1987;23:1491-6.

[87] Hecht SS, Hoffmann D. Tobacco-specific nitrosamines, an important group of carcinogens in tobacco and tobacco smoke. Carcinogenesis 1988;17:116-28.

[88] Storm HH, Dickman PW, Engeland A, Haldorsen T, Hakulinen T. Do morphology and stage explain the inferior lung cancer survival in Denmark? Eur Respir J 1999; 13:430-5.

[89] EUROCARE Working Group, Janssen-Heijnen MLG, Gatta G, Forman D, Capocaccia R, Coebergh JWW. Variation in survival of patients with lung cancer in Europe, 1985-1989. Eur J Cancer 1998;34:2191-6.

[90] Sant M, Gatta G, Capocaccia R, et al. Survival for lung cancer in northern Italy. Cancer Causes Control 1992:3:223-30.

[91] Vrdoljak E, Mise K, Sapunar D, Rozga A, Marusic M. Survival analysis of untreated patients with non-smallcell lung cancer. Chest 1994;106:1797-800.

[92] Janssen-Heijnen MLG, Schipper RM, Klinkhamer PJJM, Crommelin MA, Mooi WJ, Coebergh JWW. Divergent changes in survival for histological types of non-small-cell lung cancer in southeastern Netherlands since 1975. Br J Cancer 1998;77:2053-7.

[93] Humphrey EW, Smart CR, Winchester DP, et al. National survey of the pattern of care for carcinoma of the lung. J Thorac Cardiovasc Surg 1990;100:837-43.

[94] Hilsenbeck SG, Raub WA, Sridhar KS. Prognostic factors in lung cancer based on multivariate analysis. Am J Clin Oncol (CCT) 1993;16:301-9.

[95] Gilliland FD, Samet JM. Lung cancer. In: Doll R, Fraumeni JF, Jr, Muir CS, editors. Cancer Surveys: Trends in Cancer Incidence and Mortality, vol. 19. New York: Imperial Cancer Research Fund, 1994:175-95.

[96] Ries LAG, Miller BA, Hankey BF, et al., editors. SEER Cancer Statistics Review, 1973-1991: Tables and Graphs. Besthesda: National Institutes of Health, 1994 NIH Publication No. 94-2789.
[97] Pastorino U, Berrino F, Valente M, et al. Incident lung cancer survival: long term follow-up of a populationbased study in Italy. Tumori 1990;76:199-204.

[98] Levi F, Randimbison L, Van-Cong T, Franceschi S, La Vecchia C. Trends in cancer survival in Vaud, Switzerland. Eur J Cancer 1992;28A:1490-5.

[99] Capocaccia R, Micheli A, Berrino F, et al. Time trends of lung and larynx cancers in Italy. Int $\mathbf{J}$ Cancer 1994;57:154-61.

[100] Clerici M, Panvini D, Torri V, et al. Patterns of care and survival in non-small cell lung cancer: 15 years' experience in a general hospital. Tumori 1994;80:106-12.

[101] Rossing TH, Rossing RG. Survival in lung cancer: an analysis of the effects of age, sex, resectability, and histopathologic type. Am Rev Respir Dis 1982;126:7717.

[102] Nou E. The natural five-year course in bronchial carcinoma: epidemiologic results. Cancer 1984;53:2211-6.

[103] Capewell S. Patients presenting with lung cancer in South East Scotland. Thorax 1987;42:853-7.

[104] Foucher P, Coudert B, Arveux P, et al. Age and prognosis of non-small cell lung cancer: usefulness of a relative survival model. Eur J Cancer 1993;29A:1809-13.

[105] Grosclaude P, Galat JP, Mace-Lesech J, RoumagnacMachelard M, Mercier M, Robillard J. Differences in treatment and survival rates of non-small-cell lung cancer in three regions of France. $\mathrm{Br} \mathbf{J}$ Cancer 1995; $72: 1278-82$.

[106] Janssen-Heijnen MLG, Schipper RM, Klinkhamer PJJM, Crommelin MA, Coebergh JWW. Improvement and plateau in survival of small cell lung cancer since 1975: a population-based study. Ann Oncol 1998;9:5437.

[107] Skarin AT. Analysis of long-term survivors with smallcell lung cancer. Chest 1993;103:440S-4S.

[108] Lassen U, Osterlind K, Hansen M, Dombernowsky P, Bergman B, Hansen HH. Long-term survival in smallcell lung cancer: posttreatment characteristics in patients surviving 5 to $18+$ years: an analysis of 1,714 consecutive patients. J Clin Oncol 1995;13:1215-20.

[109] Travis WD, Travis LB, Devesa SS. Lung cancer. Cancer Suppl 1995;75:191-202.

[110] Connolly CK, Jones WG, Thorogood J, Head C, Muers MF. Investigation, treatment and prognosis of bronchial carcinoma in the Yorkshire Region of England 19761983. Br J Cancer 1990;61:579-83.

[111] Crawford SM, Atherton F. Lung cancer: histological aspects of diagnosis in England and the south east Netherlands. J Epidemiol Community Health 1994;48:420-1.

[112] Choi NC, Carey RW, Kaufman D, Grillo HC, Younger J, Wilkins EW. Small cell carcinoma of the lung: a progress report of 15 years' experience. Cancer 1987;59:6-14.

[113] Davis S, Wright PW, Schulman SF, Scholes D, Thorning D, Hammar S. Long-term survival in small-cell carcinoma of the lung: a population experience. J Clin Oncol 1985;3:80-91. 
[114] Flehinger BJ, Kimmel M, Melamed MR. The effect of surgical treatment on survival from early lung cancer: implications for screening. Chest 1992;101:1013-8.

[115] Pearson FG. Current status of surgical resection for lung cancer. Chest 1994;106(Suppl.):337S-9S.

[116] De Rijke JM, Schouten LJ, Schouten HC, Jager JJ, Koppejan AG, van den Brandt PA. Age-specific differences in the diagnostics and treatment of cancer patients aged 50 years and older in the province of Limburg, The Netherlands. Ann Oncol 1996;7:677-85.

[117] Damhuis RAM, Schütte PR. Resection rates and postoperative mortality in 7,899 patients with lung cancer. Eur Respir J 1996;9:7-10.

[118] Watkin SW, Hayhurst GK, Green JA. Time trends in the outcome of lung cancer management: a study of 9,090 cases diagnosed in the Mersey Region, 1974-1986. Br J Cancer 1990;61:590-6.

[119] Bunn PA, van Zandwijk N, Pastorino U, et al. European school of oncology first Euro-American forum on lung cancer treatment. Eur J Cancer 1994;30A:7103.

[120] Thomas P, Sielezneff I, Ragni J, Giudicelli R, Fuentes P. Is lung cancer resection justified in patients aged over 70 years? Eur J Cardiothorac Surg 1993;7:246-51.

[121] Osaki T, Shirakusa T, Kodate M, Naknishi R, Mitsudomi T, Ueda H. Surgical treatment of lung cancer in the octogenarian. Ann Thorac Surg 1994;57:188-93.

[122] Jett JR. Current treatment of unresectable lung cancer. Mayo Clin Proc 1993;68:603-11.

[123] Brodin O, Nou E, Mercke C, et al. Comparison of induction chemotherapy before radiotherapy with radiotherapy only in patients with locally advanced squamous cell carcinoma of the lung. Eur $\mathbf{J}$ Cancer 1996;32A:1893-900.

[124] Van de Wetering ML, Mooi WJ, Wagenaar SS, et al. $\mathrm{K}$-ras oncogene activation in adenocarcinoma of the lung: incidence and relation to smoking. Cancer Res 1988;48:5738-41.

[125] Kern JA, Slebos RJC, Top B, et al. C-erbB-2 expression and codon $12 \mathrm{~K}$-ras mutations both predict shortened survival for patients with pulmonary adenocarcinomas. J Clin Invest 1994;93:516-20.

[126] Rodenhuis S, Boerrigter L, Top B, et al. Mutational activation of the K-ras oncogene and the effect of chemotherapy in advanced adenocarcinoma of the lung: a prospective study. J Clin Oncol 1997;15:285-91.

[127] Pantel K, Izbicki J, Passlick B, Haussinger K, Thetter O, Riethmüller G. Frequency and prognostic significance of isolated tumour cells in bone marrow of patients with non-small-cell lung cancer without overt metastases. Lancet 1996;347:649-53.

[128] Cohen R, Guber A, Siegal A, et al. The prognostic application of cytokeratin typing of nonsmall cell lung carcinoma: a retrospective study. Cancer 1997;79:46873.

[129] Pedersen LM, Milman N. Microalbuminuria in patients with lung cancer. Eur J Cancer 1998;34:76-80.
[130] Feinstein AR. On classifying cancers while treating patients. Arch Intern Med 1985;145:1789-91.

[131] Greenberg ER, Baron JA, Dain BJ, et al. Cancer staging may have different meanings in academic and community hospitals. J Clin Epidemiol 1991;44:505-12.

[132] Satariano WA. Comorbidity and functional status in older women with breast cancer: implications for screening, treatment, and prognosis. J Gerontol 1992;47:2431.

[133] Picirrilo JF, Feinstein AR. Clinical symptoms and comorbidity: significance for the prognostic classification of cancer. Cancer 1996;77:8334-42.

[134] DeMaria LC, Cohen HJ. Characteristics of lung cancer in elderly patients. J Gerontol 1987;42:540-5.

[135] Guadagnoli E, Weitberg A, Mor V, Silliman RA, Glicksman AS, Cummings FJ. The influence of patient age on the diagnosis and treatment of lung and colorectal cancer. Arch Intern Med 1990;150:1485-90.

[136] Monfardini S, Yancik R. Cancer in the elderly: meeting the challenge of an aging population. J Natl Cancer Inst 1993;85:532-8.

[137] Wei JY. Cardiovascular comorbidity in the older cancer patient. Semin Oncol 1995;22:9-10.

[138] Ginsberg RJ, Hill LD, Eagan RT, et al. Modern thirty day operative mortality for surgical resections in lung cancer. J Thorac Cardiovasc Surg 1983;86:654-8.

[139] Nagasaki F, Flehinger BJ, Martini N. Complications of surgery in the treatment of carcinoma of the lung. Chest 1982;82:25-9.

[140] Burrows B, Earle RH. Course and prognosis of chronic obstructive lung disease: a prospective study of 200 patients. New Engl J Med 1969;280:379-404.

[141] Postma DS, Burema J, Gimeno F, et al. Prognosis in severe chronic obstructive pulmonary disease. Am Rev Respir Dis 1979;119:357-67.

[142] Merrilees MA, Scott PJ, Norris RM. Prognosis after myocardial infarction: results of 15 year follow up. $\mathrm{Br}$ Med J 1984;288:356-9.

[143] Feinstein AR, Wells CK. A clinical-severity staging system for patients with lung cancer. Medicine 1990;69:133.

[144] Satariano WA, Ragland DR. The effect of comorbidity on 3-year survival of women with primary breast cancer. Ann Intern Med 1994;120:104-10.

[145] Wong DH, Weber EC, Schell MJ, Wong AB, Anderson CT, Barker SJ. Factors associated with postoperative pulmonary complications in patients with severe chronic obstructive pulmonary disease. Anesth Analg 1995;80:276-84.

[146] Goodwin JS, Samet JM, Hunt WC. Determinants of survival in older cancer patients. $\mathbf{J}$ Natl Cancer Inst 1996;88:1031-8.

[147] Morstyn G, Ihde DC, Lichter AS, et al. Small cell lung cancer 1973-1983: early progress and recent obstacles. Int J Radiat Oncol 1984;10:515-39.

[148] Osterlind K, Hansen HH, Hansen M, Dombernowsky P. Mortality and morbidity in long-term surviving patients 
treated with chemotherapy with or without irradiation for small-cell lung cancer. J Clin Oncol 1986;4:1044-52.

[149] Findley MPN, Griffin AM, Raghaven D, et al. Retrospective review of chemotherapy for small cell lung cancer in the elderly: does the end justify the means? Eur J Cancer 1991;27:1597-601.

[150] Schiller JH, Ettinger DS, Larson MM, Gradishar W, Merkel D, Johnson DH. Phase II trial of oral etoposide plus cisplatin in extensive stage small cell carcinoma of the lung: an Eastern Cooperative Oncology Group Study. Eur J Cancer 1994;30A:158-61.

[151] Van der Gaast A, Postmus PE, Burghouts J, van Bolhuis C, Stam J, Splinter TA. Long term survival of small cell lung cancer patients after chemotherapy. $\mathrm{Br} \mathrm{J}$ Cancer 1993;67:822-4.

[152] Souhami RL, Law K. Longevity in small cell lung cancer: a report to the Lung Cancer Subcommittee of the United Kingdom Coordinating Committee for Cancer Research. Br J Cancer 1990;61:584-9.

[153] Arriagada R, Pignon JP, Ihde DC, et al. Effect of thoracic radiotherapy on mortality in limited small cell lung cancer: a meta-analysis of 13 randomized trials among 2,140 patients. Anticancer Res 1994;14:333-5.

[154] Johnson BE, Ihde DC, Bunn PA, et al. Patients with small-cell lung cancer treated with combination chemotherapy with or without irradiation: data on potential cures, chronic toxicities, and late relapses after a five- to eleven year follow-up. Ann Intern Med 1985;103:430-8.
[155] Perry MC, Eaton WL, Propert KJ, et al. Chemotherapy with or without radiation therapy in limited small-cell carcinoma of the lung. New Engl J Med 1987;316:9128.

[156] Pignon J-P, Arriagada R, Ihde DC, et al. A meta-analysis of thoracic radiotherapy for small-cell lung cancer. New Engl J Med 1992;327:1618-24.

[157] Crown JPA, Phillippe Chahinian A, Jaffrey IS, Glidewell OJ, Kaneko M, Holland JF. Predictors of 5-year survival and curability in small cell lung cancer. Cancer 1990;66:382-6.

[158] Osterlind K, Andersen PK. Prognostic factors in small cell lung cancer: multivariate model based on 778 patients treated with chemotherapy with or without irradiation. Cancer Res 1986;46:4189-94.

[159] Allan SG, Stewart ME, Love S, et al. Prognosis at presentation of small cell carcinoma of the lung. Eur $\mathbf{J}$ Cancer 1990;26:703-5.

[160] Clamon GH, Audeh MW, Pinnick S. Small cell lung carcinoma in the elderly. Am Geriatr Soc 1982;30:299302.

[161] Shepherd FA, Amdemichael E, Evans WK, et al. Treatment of small cell lung cancer in the elderly. J Am Geriatr Soc 1994;42:64-70.

[162] Siu LL, Shepherd FA, Murray N, Feld R, Pater J, Zee B. Influence of age on the treatment of limitedstage small-cell lung cancer. J Clin Oncol 1996;14:8218 . 